\title{
Polish anaesthesiology nursing documentation: a complex, multi-faceted nursing practice in the context of evidence-based professional practice
}

Polska dokumentacja pielęgniarek anestezjologicznych: kompleksowa, wieloaspektowa praktyka pielęgniarska wobec praktyki zawodowej opartej na dowodach naukowych

\section{Dorota Ozga ${ }^{1,4}$, Małgorzata Jadczak ${ }^{2,4}$, Anna Zdun ${ }^{3}$, Krystyna Woźniak ${ }^{1,5}$, Sabina Krupa ${ }^{1,5}$, Paweł Witt', ${ }^{4,5}$}

\begin{abstract}
'Kolegium Nauk Medycznych, Uniwersytet Rzeszowski/College of Medical Sciences, University of Rzeszów ${ }^{2}$ Oddział Kliniczny Neurochirurgii z Pododdziałem Traumatologii Narządu Ruchu, Uniwersyteckie Centrum Kliniczne WUM, Dziecięcy Szpital Kliniczny im. J.P. Brudzińskiego w Warszawie/ Clinical Neurosurgical Ward with an Orthopaedic Traumatology Unit, Warsaw Medical University Clinical Centre, J.P. Brudziński Clinical Pediatric Hospita

${ }^{3}$ Oddział Intensywnej Terapii , SPSK im. Orłowskiego CMKP w Warszawie/ Intensive Care Unit, Centre of Postgraduate Medical Education at the W. Orłowski Clinical Hospital in Warsaw

${ }^{4}$ Klinika Anestezjologii, Intensywnej Terapii i Opieki Pooperacyjnej, Samodzielny Publiczny Dziecięcy Szpital Kliniczny w Warszawie, Szpital Pediatryczny/ Clinical Ward for Anaesthesiology, Intensive and Postoperative Care in Warsaw, Clinical Pediatric Hospital ${ }^{5}$ Polskie Towarzystwo Pielęgniarek Anestezjologicznych i Intensywnej Opieki/ Polish Association of Anaesthesiology and Intensive Care Nurses
\end{abstract}

Dorota Ozga: 0000-0002-9457-9388

Małgorzata Jadczak: 0000-0003-1898-950X Anna Zdun: 0000-0003-2376-0312

Krystyna Woźniak: 0000-0003-3018-1079

Sabina Krupa: 0000-0002-3002-3153

Paweł Witt: 0000-0002-4053-0853

CORRESPONDING AUTHOR/AUTOR DO KORESPONDENCJI:

Dorota 0zga

Zakład Dydaktyki w Intensywnej Opiece Medycznej i Ratownictwie Medycznym

Wydział Medyczny, Uniwersytet Rzeszowski al. Rejtana 16 c, 35-959 Rzeszów e-mail: gdozga@poczta.fm

\section{PRAKTYKA PIELEZGNIARSKA WOBEC PRAKTYKI ZAWO DOWEJ OPARTEJ NA DOWODACH NAUKOWYCH}

Wprowadzenie. Badania pokazują, że dokumentacja pielęgniarska jest warunkiem dla zapewnienia ciągłości opieki nad pacjentem, jak i bezpieczeństwa pacjenta.

Cel. Celem artykułu jest przedstawienie istniejącej wiedzy na temat dokumentacji pielęgniarki anestezjologicznej i zaznaczenie niezbędnych elementów, które powinny być w niej zawarte.

Materiał i metoda. Dokonano przeglądu literatury z systematycznym poszukiwaniem materiału naukowego. Treść zawartych badań przeanalizowano za pomocą analizy zawartości i trafności doboru. Materiały pozyskano przeszukując elektroniczne bazy danych.

Wyniki. Stwierdzono, że w praktykach dokumentacyjnych pielęgniarek anestezjologicznych kluczowe są elementy takie jak: narzędzie dokumentacji musi być dostosowane do praktyki klinicznej; dokumentacja dla pielęgniarek powinna zapewniać aspekt bezpieczeństwa pacjentów i chronić pielęgniarki przed konsekwencjami prawnymi; oraz dokumentacja powinna być dostosowana do obowiązujących przepisów prawnych i cyklicznie aktualizowana.

Podsumowanie. Pielęgniarki anestezjologiczne prowadząc dokumentację zapewniają poprawę bezpieczeństwa pacjenta oraz dbają o bezpieczeństwo własne. Dzięki obserwacji i odnotowywaniu wszelkich podjętych interwencji możemy zapobiegać błędom i śledzić zmiany stanu pacjenta, które obrazuje dokumentacja chorego.

Słowa kluczowe: dokumentacja pielęgniarska, pielęgniarka anestezjologiczna, bezpieczeństwo pacjenta 
Introduction. Research demonstrates that nursing documentation is a condition for the continuity of patient care and for their safety. The objective of the article is to present the existing knowledge on anaesthesiology nursing documentation and to specify its essential elements.

Material and methods. A literature review was performed with a systematic literature search. The content of the included studies was analysed in terms of its content and relevance. The materials was gathered through electronic database search.

Results. It was found that the key elements of the documentation-related practice of anaesthesiology nurses were as follows: the record-keeping tool should be adjusted to the clinical practice, the documentation for nurses should take into consideration the patient safety aspect and protect nurses from legal consequences; also, the documentation should comply with the current legal regulations and be regularly updated.

Conclusions. Anaesthesiology nurses who keep their documentation contribute to improving the safety of patients and themselves. With observations and taking notes on all performed interventions, it is possible to prevent errors and track changes in the patient's condition reflected in their medical record.

\section{INTRODUCTION}

The level and quality of the healthcare system is an essential factor in the process of providing patients with safe medical services. Its measure may be defined through a proper analysis of any adverse events and errors, including their causes, as well as monitoring and reporting them. Paying attention to ergonomic conditioning of such events decreases their number and limits the scale of damage. Introducing an appropriate documentation for medical personnel may be an example of an appropriate preventive action. The Regulation of the Minister of Health of 16 December 2016 on the organisational standard of healthcare in the field of anaesthesiology and intensive care in Poland specifies duties connected with keeping anaesthesia charts and organising work at the anaesthesia work station [1].

Article 9 of the regulation states that the physician administering anaesthesia may be performing the procedure on only one patient at a time, with the anaesthesiology nurse working with him/her during the procedure [1]. Prior to the procedure, it is the physician's responsibility to check the necessary instruments, control the operation of medical devices essential for the anaesthesia and monitor the patient's condition, to verify whether the infusion fluids and the syringes with medications used during the procedure are labelled correctly, confirm that there is a match between the recipient's blood type and every blood unit or its components prepared for transfusion, if necessary, and finally to identify the patient. The physician performing anaesthesia should be in close proximity to the patient during the entire procedure [1]. According to Article 9 section 12 of the regulation, the physician performing the anaesthesia fills in the anaesthesia chart, which focuses particularly on the course of the anaesthesia, the dosage of anaesthetics and other drugs, current values of the basic vital functions as well as potential complications [1]. The regulation does not specify the type or model of medical documentation in which anaesthesiology nurses working at the anaesthesia work station make entries and keep documentation of their actions according to their duties and authorisations. At the same time, Polish law does not allow for replacing a physician with a nurse during any procedures which are defined as physician's duties in legal regulations [2]. Anaesthesiology nurse's duties at the anaesthesia work station are specified as a cooperation with the attending anaesthesiologist. The situation raises certain doubts as to whether a lack of documentation concerning nurses' actions may have an impact on issues of professional responsibility in case of potential claims. To address the concerns, a Work Group (WG) at the Polish Association of Anaesthesiology and Intensive Care Nurses (Polskie Towarzystwo Pielęgniarek Anestezjologicznych i Intensywnej Opieki - PTPAiIO) has established the Chart for Anaesthesiology Nurses at the Anaesthesia Work Station („Kartę Czynności Pielęgniarki Anestezjologicznej na Stanowisku Znieczulenia” - KCPASZ). The 2012 document recommends using it in the process of keeping individual patient records [2]. A literature review was performed along with a systematic search for scientific data. The subject matter of the research included was analysed in terms of content and relevance. The materials were gathered in the course of electronic database search.

\section{A literature review taking into account evidence-based nursing practice}

Medical records have a range of functions in the entire spectrum of healthcare. They support the decision-making process in the clinical environment concerning planning and performing nursing treatment, support the flow of patients between units and provide clarity on the quality and continuity of patient's care $[3,4,5,6]$. International accreditation organisations specify that treatment documentation must support clinical decision-making and facilitate the continuity of the treatment process. The documentation forms a basis for patient's safety and for the provision of nursing quality $[5,7,8]$. Furthermore, it is a basis for internationally acclaimed methods of providing quality meeting the requirements of the European Commission that determine documentation, quality control and quality development/evaluation as integral elements of medical services [5]. In this respect the documentation demonstrates the vital role of nurses in the process of improving the quality of patient's care and clinical 
quality of medical procedures [4,9]. In various scientific papers and reviews it has been pointed out that there are few global sets of regulations concerning the issue of documenting advanced perioperative nursing practice at the anaesthesia work station $[9,10]$, even though it is commonly agreed that perioperative documentation of nursing care is pivotal in ensuring patients' safety and continuity of nursing treatment within the surgical suite $[9,11,12]$. International documentation indicates that there are major differences in documenting perioperative nursing practice. A multicentre qualitative analysis [10] and literature review [4,12] pinpoint incomplete knowledge, data and understanding of perioperative documentation practice, suggesting the randomness and low quality of the data, which poses a serious threat to patient's safety. Research shows that documentation practices vary between wards and hospitals: there are organisational and individual differences concerning the content, tools and levels of nurses' engagement in the documentation process $[4,9,12]$.

\section{Analysis of Polish anaesthesiology nursing documentation in the context of evidence- based professional practice}

Keeping medical documentation is a duty of every medical institution, including physicians, nurses, paramedics and practising midwives. This obligation enables control and verification of the treatment process. Appropriate medical documentation is strictly connected to the legal responsibility of nurses [13]. If there are any claims on patient's behalf, it is the documentation that forms the basis for determining whether there has been a breach of legal regulations or professional ethics [13]. Very often medical documentation is presented by the patient's family as evidence in a court case, but it should be borne in mind that its main purpose is to record the performed procedures in such a way as to ensure the continuity of care [13]. The Regulation of the Minister of Health of 9 May 2005 on the types, scope and templates of medical records and their processing (Journal of Laws of 2015, item 2069) thoroughly describes the rules for keeping medical documentation, assigning specific duties to each of the participants in the medical treatment process. The regulation defines who (a physician, a nurse or a midwife) is legally obliged and entitled to keeping medical documentation [14]. If the ministerial regulation determines entitlements to making entries in a given document, no other person is allowed to do it. Therefore, if a person keeps such documentation despite the regulation, he or she breaches the law. It should be also remembered that the rules for keeping documentation are defined in high-level laws, i.e. regulations subordinate to acts. They cannot be regulated by means of lower-level legal acts, such as ordinances or internal rules and regulations established by managers of medical facilities. In the case of providing medical services connected with surgical anaesthesia, the Regulation of the Minister of Health of 9 May 2015 imposes an obligation of keeping individual internal documentation - patient's history, with enclosed additional documents including anaesthesia chart, surgical report and the perioperative control chart
[14]. According to the regulation, entries in the perioperative control chart are made by the chart's coordinator, i.e. the person indicated by the medical facility in its organisational rules and regulations. The aforementioned control chart contains subject marking and grouped information for actions in three categories: performed before the anaesthesia, prior to the incision and before the patient leaves the operating suite [14]. In the first part the perioperative control chart contains in particular: patient's name, surgery date, the name of the facility, patient's number in the admission and release registry, the mode of the surgery, identity confirmation, the operated region, the type of the surgical procedure, consent to the surgery, the type of anaesthesia, information on the marking of the operated region, confirmation of performing the anaesthesia safety evaluation, confirmation of the provision of basic monitoring, information on allergies, expected difficulties in maintaining patent airway paths, and haemorrhage risks $>500 \mathrm{ml}$ in adult patients or $>7 \mathrm{ml} / \mathrm{kg}$ in pediatric patients [14]. In the part concerning actions taken prior to the incision the chart contains information on whether the team members have confirmed they know their identities and functions in the surgical team and whether all of them have been introduced to each other. Unless the team members know each other, the surgeon, the anaesthesiologist, the anaesthesiology nurse and the surgical nurse should verify patient's identity, the operated region and the surgical procedure and the proper positioning of the patient, while the surgical nurse should check the set of tools. The chart should also include information on possible deviations from the planned surgical procedure, possible modifications of the type or technique of the surgery or any prolonging of the surgery time, anaesthesia type changes, expected blood loss, adding or changing the instruments by the surgeon, anaesthesiologist, surgical nurse; information on applying and documenting perioperative antibiotic prophylaxis up to 60 minutes prior to the surgery, antithrombotic prophylaxis, and preparation of imaging test results [14]. The section of the chart referring to actions taken before the patient leaves the operating suite contains in particular the team's confirmation of the name of the procedure, surgical nurse's verification of the tools and materials used, information on labelling the samples taken for tests, any complications that occurred during the surgery or malfunction of the instruments or technical difficulties. It should also include information on any potential postoperative complications stated by the surgeon and the anaesthesiologist, on postoperative recommendations formulated by the surgeon and the anaesthesiologist, and on documenting patient's condition before transferring the patient from the operating suite to the postoperative ward or room. The chart is signed by its coordinator and none of the data included refers to the work of the anaesthesiology nurse [14]. As the Polish Association of Anaesthesiology and Intensive Care Nurses, we fully support promoting safe perioperative care, whose aims have been defined in The Helsinki Declaration on Patient Safety in Anaesthesiology $[15,16,17]$. Patients have the right to feel secure and protected during all medical procedures and anaesthesiology plays a vital part 
in the process of improving patient's safety at the perioperative stage. Therefore, we fully approve and declare our intention to observe The International Standards for a Safe Practice of Anaesthesia by the World Federation of Societies of Anaesthesiologists. It is crucial for the healthcare system to educate patients and to provide them with an opportunity to give feedback, which may allow further improvements. The institutions responsible for financing healthcare system have the right to expect secure perioperative anaesthesiology services; therefore, it is their duty to arrange appropriate financial resources. As education is a key element in the process of improving patient safety, we give our full support to the development, raising awareness and conducting training on patient safety $[15,16,17]$. The human factor is essential in the process of providing treatment, which is why, in order to increase safety, we will promote the development of working standards for anaesthesiology nurses with full responsibility. The success of modern anaesthesiology is the outcome of advancement in technology, pharmacology, training and education, improved systems and a focus on human efficiency as well as the standardisation and development of guiding information. All the aspects are pivotal and have an impact on well-received and modern practice in general, but they are also closely connected to nursing care. Documentation constitutes a proof of performing all procedures in compliance with the applicable regulations. It is available free of charge on the PTPAiIO website in the Work Group tab. A register of hospitals expressing the willingness to apply the proposed documentation template at their facility is currently open. In July 2017 in Poland there were 11 Anaesthesiology and Intensive Care Units using the template. Each hospital in Poland can download and modify it for any special purposes of a given unit.

\section{The tool used for keeping documentation must be adjusted to clinical perioperative practice}

Anaesthesiology nurses often come across various technical and practical problems when documenting the nursing practice $[4,18,19]$. Designing a tool used for nursing documentation must be compliant with the clinical practice within which it is to be applied $[19,20]$. Perioperative documentation is kept along with the nursing practice, which becomes a challenge as far as timing is concerned, making it necessary to adjust the documentation tool to the specific practice $[4,18,20,21,22,23]$. Nurses working in operating suites and post-operative rooms deal with patient safety on a daily basis, and thus point to a connection between a good medical documentation and patient's safety $[4,24,25]$. In perioperative practice emphasis is placed on issues such as the mentioned patient's safety, preventing patient's injuries and a coherent patient's treatment path $[4,18,25]$.

To sum up, it is important for the documenting tools to be adjusted to the particular clinical practice and cover many aspects of this practice. The documentation must facilitate navigation through procedures and provide a transparent basis for data analysis. It must be easily available, reliable and enable simultaneous record-keeping. A number of the requirements refer to the working conditions of anaesthesiology nurses, in particular to the considerable time pressure. If a given tool does not meet the expectations and requirements, there is less focus on the record-keeping, what leads to incomplete and inaccurate data. Furthermore, under such conditions nurses tend to omit the record-keeping and depend on the tools used by other staff members, what influences the process of patient care.

\section{CONCLUSIONS}

Introducing the chart makes it possible to increase patient's safety, maintain a safe workplace, increase anaesthesiology nurses' awareness of their responsibility, receive information on the causes of adverse events, keep their registry and introduce the necessary changes. According to the recommendations of the PTPAiIO Work Group, the Activity Chart should be on the list of obligatory or at least supplementary internal patient records.

\section{Polska dokumentacja pielęgniarek anestezjologicznych: kompleksowa, wieloaspektowa praktyka pielęgniarska wobec praktyki zawodowej opartej na dowodach naukowych}

\section{WPROWADZENIE}

Poziom i jakości systemu ochrony zdrowia decyduje o bezpieczeństwie pacjentów korzystających $\mathrm{z}$ usług medycznych. Miernikiem oceny ochrony zdrowia może być właściwa analiza przyczyn, monitorowanie i raportowanie zdarzeń niepożądanych i błędów medycznych. Zwracanie uwagi na ergonomiczne uwarunkowania tych zdarzeń zmniejsza ich liczbę i ogranicza zakres szkód. Przykładem właściwego działania o charakterze prewencyjnym wobec błędów medycznych może być wprowa- dzenie odpowiedniej dokumentacji dla personelu medycznego. Rozporządzenie Ministra Zdrowia z dnia 16 grudnia 2016 r. w sprawie standardu organizacyjnego opieki zdrowotnej w dziedzinie anestezjologii i intensywnej terapii w Polsce określa obowiązki związane z prowadzeniem karty znieczulenia i organizacją pracy na stanowisku znieczulenia [1]. W §9 tego Rozporządzenia stwierdza się między innymi, że lekarz wykonujący znieczulenie może w tym samym czasie znieczulać tylko jednego pacjenta, a podczas znieczulenia z lekarzem współpracuje pielęgniarka anestezjologiczna [1]. Przed przystąpieniem 
do znieczulenia to lekarz wykonujący znieczulenie jest obowiązany: sprawdzić wyposażenie stanowiska znieczulenia, skontrolować sprawność działania wyrobów medycznych niezbędnych do znieczulenia i monitorowania, skontrolować właściwe oznakowanie płynów infuzyjnych, strzykawek z lekami stosowanymi podczas znieczulenia, przeprowadzić kontrolę zgodności krwi biorcy z każdą jednostką krwi lub jej składnika przeznaczoną do przetoczenia w przypadku konieczności jej toczenia, dokonać identyfikacji pacjenta. Lekarz wykonujący znieczulenie powinien znajdować się w bezpośredniej bliskości pacjenta przez cały czas trwania znieczulenia [1]. Zgodnie z $\$ 9$ pkt 12 przytoczonego rozporządzenia lekarz wykonujący znieczulenie wypełnia kartę przebiegu znieczulenia, uwzględniającą w szczególności jego przebieg, dawkowanie anestetyków i innych leków, aktualne wartości parametrów podstawowych funkcji życiowych oraz ewentualne powikłania [1]. Wymieniony akt prawny nie określa rodzaju, ani wzoru dokumentacji medycznej, w której pielęgniarka anestezjologiczna pracująca na stanowisku znieczulenia ma obowiązek i uprawnienia do dokonywania wpisów i dokumentowania swoich działań zawodowych. Jednocześnie zgodnie z polskim prawem, nie jest możliwe zastąpienie przez pielęgniarkę lekarza podczas wykonywania czynności, które na podstawie obowiązujących przepisów prawnych należą do niego [2]. Zadania zawodowe pielęgniarki anestezjologicznej na stanowisku znieczulenia określone zostały, jako współpraca z lekarzem prowadzącym znieczulenie. Sytuacja ta wzbudza pewne wątpliwości, czy brak dokumentowania czynności wykonywanych przez pielęgniarki anestezjologiczne nie będzie miał wpływu na kwestie odpowiedzialności zawodowej w przypadku wystąpienia roszczenia. W odpowiedzi na te wątpliwości Grupa Robocza(GR) działająca przy Polskim Towarzystwie Pielęgniarek Anestezjologicznych i Intensywnej Opieki (PTPAiIO) w lutym 2012 roku opracowała „Kartę Czynności Pielęgniarki Anestezjologicznej na Stanowisku Znieczulenia - KCPASZ" i zaleca jej stosowanie $\mathrm{w}$ ramach prowadzenia indywidualnej dokumentacji pacjenta [2]. Dokonano przeglądu literatury z systematycznym poszukiwaniem materiału naukowego. Treść zawartych badań przeanalizowano za pomocą analizy zawartości i trafności doboru. Materiały pozyskano przeszukując elektroniczne bazy danych.

\section{Przeglad piśmiennictwa w oparciu o EBN praktykę opartą na dowodach naukowych}

Dokumentacja medyczna obejmuje szereg funkcji w całej ochronie zdrowia. Wspiera ona proces podejmowania decyzji klinicznych w związku z planowaniem i opieką pielęgniarską, wspiera proces przepływu pacjentów pomiędzy jednostkami i zapewnia przejrzystość w zakresie jakości i ciągłości opieki nad pacjentem $[3,4,5,6]$. Międzynarodowe organizacje akredytacyjne precyzują, że dokumentowanie udzielania świadczeń pacjenta musi wspierać kliniczne podejmowanie decyzji i ułatwiać ciągłość ścieżki procesu leczenia pacjenta; dokumentacja stanowi warunek bezpieczeństwa pacjentów i zapewnienia jakości w pielęgniarstwie $[5,7,8]$. Ponadto dokumentacja stanowi podstawę uznanych na arenie międzynarodowej metod zapewnienia jakości, takich jak wymóg Komisji Europejskiej, że dokumentacja, kontrola jakości i rozwój/ ewaluacja jakości stanowią integralną część usług medycznych [5]. W tym wypadku taki materiał udowadnia, że pielęgniarska odgrywa kluczową rolę w poprawie jakości opieki nad pacjentem i jakości klinicznej/ postępowania leczniczego $[4,9]$. W szeregu prac naukowych i opracowań praktycznych wskazano, że istnieje niewiele globalnych zbiorów wymagań dotyczących dokumentowania zaawansowanej praktyki pielęgniarskiej w okresie okołooperacyjnym na stanowisku znieczulenia $[9,10]$, chociaż istnieje ogólna zgoda co do tego, że dokumentowanie okołooperacyjnej opieki pielęgniarskiej ma kluczowe znaczenie dla bezpieczeństwa pacjentów i ciągłości opieki pielęgniarskiej w obrębie bloku operacyjnego $[9,11,12]$. Akta międzynarodowe wskazują, że istnieją znaczne różnice w praktykach dokumentacyjnych w pielęgniarstwie okołooperacyjnym. Wieloośrodkowa analiza jakościowa [10] i przeglądy literatury $[4,12]$ podają niepełną wiedzę, dane i zrozumienie praktyki dokumentacji okołooperacyjnych pielęgniarek, sugerując, że dane charakteryzują się przypadkowością i niską jakością, co powoduje poważne zagrożenia bezpieczeństwa pacjentów. Badania wskazują, że praktyki dotyczące dokumentacji różnią się w zależności od poszczególnych oddziałów i szpitali; istnieją różnice organizacyjne i indywidualne w treści, narzędziach i poziomach zaangażowania pielęgniarek $\mathrm{w}$ dokumentację $[4,9,12]$.

\section{Analiza dokumentacji pielęgniarki anestezjologicznej w Polsce, a praktyka zawodowa oparta na dowodach naukowych}

Prowadzenie dokumentacji medycznej stanowi obowiązek każdego podmiotu leczniczego, a także lekarza, pielęgniarki, ratownika medycznego oraz położnej prowadzących praktykę. Obowiązek ten ma między innymi zapewnić możliwość kontroli i weryfikacji tego, czy proces udzielania świadczeń zdrowotnych przebiegał prawidłowo. Prawidłowe prowadzenie obowiązującej dokumentacji jest ściśle powiązane $\mathrm{z}$ odpowiedzialnością prawną pielęgniarek [13]. W przypadku zgłoszenia przez pacjenta lub jego rodzinę roszczeń, to właśnie analiza dokumentów będzie stanowiła dla organów prowadzących postępowanie podstawę do sformułowania wniosku czy doszło do naruszenia reguł prawnych lub zasad etyki zawodowej, czy też nie [13]. Wielokrotnie, dokumentacja medyczna zostaje przedstawiana przez rodziny pacjentów, jako dowód w sprawie sądowej, ale należy pamiętać, że głównym celem prowadzenia dokumentacji medycznej jest przedstawienie prowadzonych interwencji tak, aby zachowana została ciągłość opieki [13]. Obowiązujące w Polsce od 9 maja 2015 roku Rozporządzenie Ministra Zdrowia w sprawie rodzajów, zakresu i wzorów dokumentacji medycznej oraz sposobu jej przetwarzania (Dz. U. z 2015 roku Poz. 2069) szczegółowo reguluje zasady prowadzenia dokumentacji medycznej, przypisując każdemu z podmiotów uczestniczących w realizacji świadczeń określone zadania. Rozporządzenie to określa między innymi, kto (lekarz, pielęgniarka czy położna) ma obowiązek prawny i jest uprawniony do prowadzenia określonej dokumentacji 
medycznej [14]. W przypadku, gdy Rozporządzenie MZ szczegółowo określa uprawnienia do dokonywania wpisów w danym dokumencie, wtedy nikt inny nie ma takiego uprawnienia, a jeżeli pomimo zapisu prowadzi taką dokumentację, to narusza przepisy prawa. Pamiętać należy również, że zasady prowadzenia dokumentacji medycznej określone w akcie prawnym wysokiej rangi, czyli rozporządzeniu podlegającemu ustawie, nie mogą być regulowane aktami niższego rzędu np. zarządzeniami czy regulaminami wewnętrznymi określonymi przez osoby zarządzające podmiotami leczniczymi. W przypadku udzielania świadczeń zdrowotnych związanych ze znieczuleniem pacjenta do zabiegu operacyjnego Rozporządzenie Ministra Zdrowia w sprawie rodzajów, zakresu i wzorów dokumentacji medycznej oraz sposobu jej przetwarzania $\mathrm{z}$ dnia 9 maja 2015 roku narzuca obowiązek prowadzenia wewnętrznej dokumentacji indywidualnej historii choroby, do której dołącza się dokumenty dodatkowe, w tym między innymi kartę przebiegu znieczulenia, protokół operacyjny, okołooperacyjną kartę kontrolną [14]. Zgodnie z Rozporządzeniem MZ wpisy w okołooperacyjnej karcie kontrolnej są dokonywane przez koordynatora karty, którym jest osoba określona w regulaminie organizacyjnym podmiotu leczniczego. Karta kontrolna, o której mowa powyżej zawiera oznaczenie podmiotu oraz pogrupowane informacje dotyczące niezbędnych czynności wykonywanych: przed znieczuleniem pacjenta, przed wykonaniem nacięcia, przed opuszczeniem przez pacjenta bloku operacyjnego [14]. W części dotyczącej czynności wykonywanych przed znieczuleniem pacjenta zawiera w szczególności: imię i nazwisko pacjenta, datę operacji, nazwę komórki organizacyjnej, w której pacjent przebywał, numer pacjenta w księdze głównej przyjęć i wypisów, określenie trybu wykonania operacji, potwierdzenie tożsamości pacjenta, miejsca operowanego, procedury operacyjnej, zgody na operację, rodzaju znieczulenia, informację o oznaczeniu miejsca operowanego, potwierdzenie dokonania oceny bezpieczeństwa przebiegu znieczulenia, potwierdzenie zapewnienia monitorowania w stopniu podstawowym, informację o alergiach, informację o przewidywanych trudnościach w utrzymaniu drożności dróg oddechowych, informację o ryzyku krwawienia $>500 \mathrm{ml}$ $\mathrm{u}$ dorosłych albo $>7 \mathrm{ml} / \mathrm{kg}$ masy ciała u dzieci [14]. Ta właśnie karta, w części dotyczącej czynności wykonywanych przed wykonaniem nacięcia zawiera w szczególności: informację o potwierdzeniu przez członków zespołu operacyjnego, że znają wzajemnie swoją tożsamość oraz funkcję w zespole operacyjnym, informację o przedstawieniu się wszystkich członków zespołu - w przypadku, gdy członkowie zespołu operacyjnego nie znają się wzajemnie, potwierdzenie przez operatora, anestezjologa, pielęgniarkę anestezjologiczną i pielęgniarkę operacyjną: tożsamości pacjenta, miejsca operowanego, procedury operacyjnej, potwierdzenie właściwego ułożenia pacjenta, potwierdzenie przez pielęgniarkę operacyjną właściwego zestawu narzędzi, informację o możliwych odstępstwach od zaplanowanej procedury operacyjnej, w szczególności zmianie typu lub techniki operacji, wydłużeniu czasu operacji, zmianie rodzaju znieczulenia, oczekiwanej utracie krwi, uzupełnieniu lub zmianie zestawu narzędzi: przez opera- tora, przez anestezjologa, przez pielęgniarkę operacyjną, informację o zastosowaniu i udokumentowaniu okołooperacyjnej profilaktyki antybiotykowej w okresie do 60 minut przed operacją, informację o zastosowaniu profilaktyki przeciwzakrzepowej, informację o przygotowaniu wyników badań obrazowych [14]. Okołooperacyjna karta kontrolna w części dotyczącej czynności wykonywanych przed opuszczeniem przez pacjenta bloku operacyjnego zawiera w szczególności: potwierdzenie przez zespół operacyjny nazwy wykonanej procedury, potwierdzenie przez pielęgniarkę operacyjną zgodności liczby użytych narzędzi i materiałów, informację o oznaczeniu materiału pobranego do badań, informację o wystąpieniu powikłań w trakcie operacji, informację o wystąpieniu problemów ze sprzętem lub trudności technicznych, informację o określeniu przez operatora i anestezjologa ewentualnych problemów pooperacyjnych, informację o wypisaniu zleceń pooperacyjnych przez: operatora, anestezjologa, informację o udokumentowaniu oceny stanu pacjenta przed przekazaniem z bloku operacyjnego do oddziału pooperacyjnego albo sali pooperacyjnej. Okołooperacyjną kartę kontrolną podpisuje koordynator karty, a żadna z zawartych danych nie dotyczy czynności wykonywanych przez pielęgniarkę anestezjologiczną [14]. W pełni przyłączamy się, jako Polskie Towarzystwo Pielęgniarek Anestezjologicznych i Intensywnej Opieki do promowanil bezpiecznej opieki okołooperacyjnej, której cele zostały szczegółowo opisane w The Helsinki Declaration on Patient Safety in Anaesthesiology [15,16,17]. Pacjenci mają prawo oczekiwać bezpieczeństwa i ochrony podczas udzielania świadczeń zdrowotnych, a anestezjologia odgrywa kluczową rolę w poprawie bezpieczeństwa pacjenta w okresie okołooperacyjnym. W związku z tym w pełni akceptujemy i deklarujemy gotowość do przestrzegania Międzynarodowych Standardów Bezpiecznego Znieczulenia Światowej Federacji Towarzystw Anestezjologicznych. Ważną rolę w bezpiecznej opiece zdrowotnej pełnią pacjenci, których należy edukować i którym należy stwarzać możliwość przekazywania informacji zwrotnej umożliwiającej dalszą poprawę procesu znieczulenia. Podmioty odpowiedzialne za finansowanie systemu ochrony zdrowia mają prawo oczekiwać bezpiecznych świadczeń z zakresu okołooperacyjnej opieki anestezjologicznej i dlatego ich obowiązkiem jest zapewnienie odpowiednich środków finansowych. Edukacja odgrywa istotną rolę w poprawie bezpieczeństwa pacjenta, w związku z czym udzielamy pełnego poparcia dla rozwoju, upowszechnienia i przeprowadzania szkoleń z zakresu bezpieczeństwa pacjenta $[15,16,17]$. Czynniki ludzkie są istotnym elementem w procesie sprawowania opieki nad pacjentem, dlatego dla podniesienia bezpieczeństwa będziemy odpowiedzialnie promować standardy pracy pielęgniarki anestezjologicznej. Sukcesy nowoczesnej anestezjologii wynikają z udoskonalonej technologii, farmakologii, szkoleń i edukacji, ulepszonych systemów, skupienia się na ludzkiej skuteczności, a także standaryzacji i rozwoju informacji przewodnich. Wszystkie te aspekty są kluczowe i mają znaczenie dla dobrze tolerowanej i nowoczesnej praktyki ogólnie, ale i odnoszą się w zdecydowany sposób do opieki pielęgniarskiej. Dokumentacja stanowi dowód wykonania wszystkich 
czynności zgodnie z obowiązującym prawem i dostępna jest bezpłatnie na stronie internetowej PTPAiIO/zakładka Grupa Robocza. Przez cały czas prowadzony jest rejestr szpitali zgłaszających chęć zastosowania wzoru dokumentacji w swojej palcówce medycznej. Do lipca 2017 roku stosuje ją na swoich oddziałach AiIT 11 szpitali w Polsce. Każdy szpital w Polsce może pobrać bezpłatnie i modyfikować wzór dokumentacji w zależności od specjalistki danej jednostki.

\section{Narzędzie dostosowane do okołooperacyjnej praktyki klinicznej}

Pielęgniarki anestezjologiczne, napotykają szereg technicznych i praktycznych problemów związanych z praktykami dotyczącymi dokumentacji pielęgniarskiej $[4,18,19]$. Projekt narzędzia do dokumentacji musi być dostosowany i zgodny z praktyką kliniczną, w której ma być stosowany $[19,20]$. Dokumentacja okołooperacyjna wykonywana jest równolegle z praktyką pielęgniarską; stanowi to wyzwanie czasowe, co powoduje, że narzędzie do dokumentacji musi być dostosowane do praktyki, w której ma być stosowane $[4,18,20,21,22,23]$. Pielęgniarki bloku operacyjnego i sali pooperacyjnej zajmują się bezpieczeństwem pacjentów i wskazują na związek między dobrą dokumentacją medyczna a bezpieczeństwem pacjentów $[4,24,25]$. W praktyce okołooperacyjnej, nacisk kładziony jest na bezpieczeństwo pacjenta, zapobieganie urazom pacjenta i koherencję ogólnej ścieżki pacjenta $[4,18,25]$.

Podsumowując, ważne jest, aby narzędzie używane do dokumentacji było dostosowane do konkretnych praktyk klinicznych i aby narzędzie to obejmowało wiele aspektów. Dokumentacja musi ułatwić nawigację po procedurach i pozwolić w sposób przejrzysty przeanalizować dane. Narzędzie to musi być łatwo dostępne i niezawodne, a dokumentacja musi być możliwa jednoczasowo do wypełnienia i wykonywania czynności. Szereg tych wymagań odnosi się do warunków pracy pielęgniarek anestezjologicznych, w szczególności do znacznej presji czasu, z jaką bardzo często napotykają. Jeśli narzędzie nie spełnia oczekiwań i wymagań, wynikiem jest mniejsze skupienie się na dokumentacji, co prowadzi do niepełnych i niedokładnych danych. Ponadto pielęgniarki pomijają dokumentację i polegają na narzędziach innych członków zespołu terapeutycznego, co ma wpływ na proces pielęgnowania pacjenta.

\section{PODSUMOWANIE}

Wprowadzenie karty pozwala na zwiększenie bezpieczeństwa pacjentów, zachowanie bezpiecznego środowiska pracy, zwiększenie odpowiedzialności za zachowanie bezpiecznych warunków pracy, wzrost świadomości odpowiedzialności pielęgniarek anestezjologicznych, otrzymanie informacji na temat przyczyn zdarzeń niepożądanych w pielęgniarstwie anestezjologicznym, ich rejestru i modyfikacji zachowań. „Karta czynności” zgodnie z zaleceniami Grupy Roboczej PTPAiIO powinna znaleźć się w wykazie obowiązkowej lub minimum dodatkowej wewnętrznej, indywidualnej dokumentacji chorego.

\section{REFERENCES/PIŚMIENNICTWO}

1. Rozporządzenie Ministra Zdrowia z dnia 16 grudnia 2016 r. w sprawie standardu organizacyjnego opieki zdrowotnej $w$ dziedzinie anestezjologii i intensywnej terapii (Dz. U z dnia 29 grudnia 2016 r. Poz. 2218).

2. Zalecenie Grupy Roboczej do spraw Praktyki w Pielęgniarstwie Anestezjologicznym i Intensywnej Opiece PTPAil0 dotyczące dokumentacji pielęgniarki anestezjologicznej. http://www.ptpaio.pl/dokumenty/5.pdf

3. Alexander EL, Rothrock JC, Mcewen DR. Alexander's Care of the Patient in Surgery, 2011, 14th. Mosby/Elsevier, St. Louis, MO.

4. Braaf S, Manias E, Riley R. The role of documents and documentation in communication failure across the perioperative pathway. A literature review. International Journal of Nursing Studies. 2011; 48: 1024-1038.

5. Joint Commission (2019) Joint Commission International. Available at: http://www. jointcommission.org/ (accessed 30 January 2019).

6. WHO (2018) Patient Safety. Available at: http://www.who.int/patientsafety/en/ (accessed 2 January 2019).

7. International Federation of Perioperative Nurses (2014) Guideline for Developing Standards, Patient Safety - Our Primary Goal. Available at: https://www.inmo.ie/ tempDocs/EORNA\%20IFPN\%20Patient\%20Safety.pdf(13 January 2019)

8. AORN Perioperative Nursing Data Set [Homepage of Association of Perioperative Registered Nurses] [0nline]. Available at: http://www.aorn.org/education/facilitysolutions/aorn-syntegrity/aorn-syntegrity-standardized-documentation (accessed 17 January 2019).

9. Chappy S. Perioperative patient safety: a multisite qualitative analysis. Association of Operating Room Nurses Journal. 2006; 83: 871-874, 877-888, 891-897.

10. Junttilla K, Lauri S, Salantera S, Hupli M. Initial validation of the perioperative nursing data set in Finland. Nursing Diagnosis. 2002; 13: 41-52.

11. Lee $E$, Lee $M$. Comparison of nursing interventions performed by medicalsurgical nurses in Korea and the United States. International Journal of Nursing Terminologies and Classifications. 2006; 17: 108-117.

12. Wilbanks BA. An integrative literature review of contextual factors in perioperative information management systems. Computers, Informatics, Nursing. 2013; 31: 622-628.

13. Rudnik K. Odpowiedzialność prawna i dokumentacja medyczna pielęgniarki anestezjologicznej. Pielęgniarstwo w anestezjologii i intensywnej opiece. 2015; 1(3): $145-148$

14. Rozporządzenie Ministra Zdrowia z dnia 9 maja 2015 roku w sprawie rodzajów, zakresu i wzorów dokumentacji medycznej oraz sposobu jej przetwarzania (Dz. U z dnia 8 grudnia 2015 r. Poz. 2069).

15. Mellin-Olsen J, Staender S, Whitaker DK, Smith AF. The Helsinki Declaration on Patient Safety in Anaesthesiology. Eur J Anaesthesiol. 2010; 27(7): 592-597.

16. Petrini F, Solca M, De Robertis E, et al.The Helsinki Declaration on Patient Safety in Anesthesiology: a way forward with the European Board and the European Society of Anesthesiology. Minerva Anestesiol. 2010; 76(11): 971-977.

17. Whitaker DK, Brattebø G, Smith AF, Staender SE. The Helsinki Declaration on Patient Safety in Anaesthesiology: putting words into practice. Best Pract Res Clin Anaesthesiol. 2011; 25(2): 277-290.

18. Sorensen EE, Olsen I0, Tewes M, Uhrenfeldt L. Perioperative nursing in public university hospitals: an ethnography. Bio Med Central Nursing. 2014; 13: 1-9.

19. Usselmann E, Borycki EM, Kushniruk AW. The Evaluation og Electronic Perioperative Nursing Documentation Using a Cognitive Walkthrough Approach.2015

20. Yontz LS, Zinn JL, Schumacher EJ. Perioperative nurses' attitudes toward the electronic health record. Journal of Perianesthesia Nursing. 2015; 30: 23-32

21. Killen AR, Kleinbeck SV, Gollar K, et al. The prevalence of perioperative nurse clinical judgments. Association of Operating Room Nurses Journal. 1997; 65: 101-108.

22. Tiusanen TS, Junttila K, Leinonen T, Salantera S. The validation of AORN recommended practices in Finnish perioperative nursing documentation. Association of Operating Room Nurses Journal. 2010; 91: 236-247.

23. Aholaakko TK. Reducing surgical nurses' aseptic practice-related stress. Journal of Clinical Nursing. 2011; 20: 3339-3350

24. Junttila K, Salantera S, Hupli M. Perioperative documentation in Finland. Association of Operating Room Nurses Journal. 2000; 72: 862-866, 868, 870-873.

25. Park HA, Lee HJ, Yoon K. The perioperative nursing data set in Korean: translation, validation, and testing. Association of Operating Room Nurses Journal. 2007; 86: 424-445.

Manuscript received/Praca zgłoszona do czasopisma: 30.01.2019

Manuscript accepted/Praca zaakceptowana do druku: 27.08.2019

Translation/Tłumaczenie: Agnieszka Ochniowska-Flor 